\title{
PENGARUH PELATIHAN “PENGASUHAN IBU CERDAS" TERHADAP STRES PENGASUHAN PADA IBU DARI ANAK AUTIS
}

\author{
Fina Hidayati \\ Fakultas Psikologi \\ Universitas Islam Negeri (UIN) Maulana Malik Ibrahim Malang \\ Jl. Gajayana 50 Malang Telp. 0341-558916 \\ email: f.guidance@yahoo.com
}

\begin{abstract}
Past research has shown that parents of children with autism had the highest parenting stress than parents of children with other disabilities. This study aims to determine the effect of training "pengasuhan ibu CERdaS" of parenting stress in mothers of children with autism. The study subjects are 20 mothers of children with autism who experience parenting stress from midle to high category, which is divided into an experimental group and control group. The experimental group are 10 people, and the control group are 10 people (waiting list). Training " pengasuhan ibu CERdaS " is given by 7 sessions in the twice meetings. Parenting stress was measured using a scale of PSI (Parenting Stress Index) before being given the training (pretest), administered after training (posttest), and a week after treatment (follow-up). quantitative analysis using statistical techniques of analysis Wilcoxon signed rank (non-parametric) to know the differences between two samples. Based on quantitative data analysis of pretest and posttest measurements of the experiment for the group: the value of $Z=-2.499$ and 0.012 significance level $(p<0.05)$, indicating a significant decrease in parenting stress in the experimental group after the training is given. Thus training "pelatihan ibu CERdaS" could statistically reduce parenting stress in mothers of children with autism.
\end{abstract}

Key words: Training "Pelatihan Ibu CERdaS", parenting stress, mother of autism child.

PSIKOISLAMIKA. Jurnal Psikologi Islam (JPI) copyright @ 2013 Laboratorium Penelitian, Kajian Psikologi Islam dan Penerbitan. Volume 10. Nomor 1, Tahun 2013

\section{PENDAHULUAN}

Autisme merupakan gangguan proses perkembangan yang terjadi dalam tiga tahun pertama kehidupan, meliputi gangguan pada bidang komunikasi, bahasa, kognitif, sosial dan fungsi adaptif (Neitzel, 2010; Sutadi, 2002; Pediatric, 2004). Dalam perkembangan anak yang normal, mulai berinteraksi dengan ibunya pada usia 3-4 bulan, dan sudah bisa memperhatikan orang yang mengajaknya bermain dan berbicara pada umur 6-8 bulan. Kemampuan ini pada anak autisme tidak muncul atau sangat kurang (Yusuf, 2003). Autisme merupakan kelainan perkembangan terberat dan paling sulit untuk ditangani. Autisme bisa terwujud dalam karakteristik atau gejala-gejala dengan berbagai kombinasi dari yang sangat ringan sampai sangat parah, sehingga sering mengakibatkan disabilitas seumur hidup bagi penderita, menjadi beban sosial ekonomi dan membuat frustasi keluarganya (Osborne \& McHugh, 2009).

Banyaknya beban yang dirasakan ibu sebagai figur terdekat anak autis dalam mengasuh anak akan menimbulkan stres pengasuhan. Kondisi stres ibu yang memiliki anak autis akan menyebabkan ibu mengalami gangguan dalam proses pengasuhan. Hal ini sesuai dengan model stres pengasuhan yang dikemukakan Abidin (Phelps et al., 2009) bahwa stres mendorong ke arah tidak berfungsinya pengasuhan 
orangtua terhadap anak. Sikap ibu yang mengalami stres akan memperparah keadaaan anak yang memiliki sindroma autisme. Hal ini akan berakibat buruk dalam pengasuhan karena stres yang dialami seringkali membuat ibu berperilaku tidak sehat dan tidak positif seperti menelantarkan anaknya bahkan berlaku kasar terhadap anaknya. Stres pengasuhan juga akan menghambat pekerjaan yang biasa dilakukan sehari-hari bahkan menghambat pertumbuhan anak dalam kehidupannya. Ibu yang tidak bisa menerima kenyataan atas kondisi anaknya hanya akan terpuruk dan bahkan tidak mau melakukan apapun untuk mendukung perkembangan anaknya. Akibatnya, ibu hanya berdiam diri dan kondisi keterbelakangan anak semakin parah. Orangtua khususnya ibu harus mampu mengatasi stres dan segera bangkit untuk melakukan yang terbaik bagi anak (Davis \& Carter, 2008).

Stres pengasuhan merupakan merupakan stres yang dialami orangtua dalam proses pengasuhan yang melibatkan serangkaian cara mengatasi perilaku dan berkomunikasi dengan anak (sosialisasi, pengajaran), perawatan atau pengasuhan (mengasuh, melindungi), mencari penyembuhan bagi anak, serta pengaruh stres tersebut terhadap kehidupan pribadi dan keluarga (Dabrowska \& Pisula, 2010).

Permasalahan yang sering muncul di masyarakat meskipun anak autis telah mengikuti program ditempat terapi autis dan mendapatkan obat-obatan, namun masih ditemukan anak autis yang tidak memperoleh kesembuhan secara optimal. Salah satu faktor yang mempengaruhi yaitu intensitas penanganan anak autis selama dirumah yang kurang efektif (Dunn, Burbine, Bowers \& Tanleff, 2001). Untuk mencapai intensitas penanganan terapi yang ideal, diperlukan dukungan dan partisipasi dari seluruh keluarga terutama ibu yang lebih berperan dalam mengasuh anak dirumah. Akan tetapi tidak semua ibu dapat berpartisipasi dalam penanganan anak autis secara khusus selama anak dirumah. Hal ini kemungkinan disebabkan oleh kurangnya pengetahuan ibu tentang penanganan anak autisme, dan sikap ibu yang lebih menyerahkan penanganan anak hanya ditempat terapi (Kazdin \& Whitley, 2003).

Ibu anak autis harus mampu menyeimbangkan berbagai kondisi yang cenderung menekan stabilitas kognisi dan afeksinya sehingga tidak terjerumus kedalam bentuk depresi. Ketahanan ibu anak autis harus dikembangkan dan dilatih, seperti pemahaman tentang perkembangan anak autis, pengelolaan stres, kemampuan memecahkan masalah, dan kepercayaan diri untuk berinteraksi dengan ligkungan sosial (Ruminem, 2005).

Beberapa intervensi dapat dilakukan untuk meningkatkan pemahaman orangtua tentang pengasuhan, sehingga akan mengurangi stres pengasuhan pada ibu yang memiliki anak autis. Salah satunya adalah positive parenting programtriple $P$, yang dikemukakan oleh Sanders pada tahun 1999. Triple $P$ merupakan program yang bertujuan untuk meningkatkan pengetahuan, ketrampilan, dan kepercayaan diri orangtua. Program ini mempromosikan perawatan, keamanan, keeratan, tanpa kekerasan dan menciptakan lingkungan tanpa konflik pada anak. Program ini dapat diterapkan dalam populasi masyarakat dan melibatkan banyak pihak yang berwenang (Sanders, 2003; Dean et al., 2003).

Penelitian yang dilakukan oleh Dean et al., (2003) membuktikan bahwa program triple P efektif menurunkan perilaku distruktif anak, menunjukkan level disfungsional orangtua dan konflik orangtuaanak dalam pengasuhan yang menurun, serta meningkatkan kesehatan mental orangtua. Program triple $P$ juga dapat menurunkan masalah perilaku dan reaksi yang berlebihan pada anak, serta menurunkan konflik orangtua dengan anak, yang berefek pada meningkatnya kompetensi orangtua (Matsumoto, Sofronoff \& Saders, 2007). Pada hasil penelitian Anastapouluos (dalam Pouretemad et al., 2009) membuktikan bahwa edukasi perlakuan dengan triple $P$ efektif meningkatkan interaksi orangtua-anak, meningkatkan harga diri orangtua dan mengurangi stres orangtua.

Pelatihan ketrampilan pengasuhan salah satu metode yang digunakan untuk memberikan tambahan pengetahuan kepada orangtua tentang bagaimana cara pengasuhan yang tepat untuk anak autis dan mengatasi stres orangtua. Jika orangtua tidak cukup mendapatkan edukasi yang bermanfaat maka stres orangtua akan memperburuk hubungan orangtuaanak, terutama pada anak dengan gangguan perilaku (Pouretemad et al., 2009).

Berdasarkan uraian di atas, maka hipotesis yang diajukan pada penelitian ini adalah pengaruh pelatihan "Pengasuhan Ibu CERdaS" dapat menurunkan stres pengasuhan pada ibu dari anak autis.

\section{METODE}

Rancangan eksperimen yang digunakan adalah The untreated control group design with pretest and posttest. Pada penelitian ini menggunakan 1 kelompok eksperimen dan 1 kelompok kontrol yang diberi pretest sebelum perlakuan, kemudian 
diberikan posttest setelah perlakuan (Shadish, Cook \& Campbell, 1979).

Rancangan Eksperimen :

\begin{tabular}{llll}
\hline 01 & $X$ & 02 & 03 \\
01 & 0 & 02 & 03 \\
\hline
\end{tabular}

\section{Keterangan}

01 : Pengukuran sebelum pelatihan (pretest)

02 : Pengukuran setelah pelatihan (posttest)

03 : Pengukuran seminggu setelah pelatihan

(follow-up)

$X$ : Pelatihan "Pengasuhan Ibu CERdaS"

- $\quad$ : Tidak diberi perlakuan

Subjek pada penelitian ini sejumlah 20 yang terbagi menjadi kelompok eksperimen dan kelompok kontrol. Kelompok ekperimen bejumlah 10 orang, dan kelompok kontrol 10 orang. Dengan kriteria; memiliki anak autis (usia 3-10 tahun), ibu berusia
22-49 tahun, tingkat pendidikan minimal SMA, bersedia mengikuti pelatihan, memiliki skor stres pengasuhan pada kategori sedang sampai tinggi, dan subjek merupakan ibu dari anak autis.

Metode pengumpulan data pada penelitian ini menggunakan skala psikologi. Skala pengukuran psikologis yang digunakan dalam penelitian ini adalah Parenting Stress Index (Abidin, 1999) yang sudah dimodifikasi. Skala ini digunakan sebagai alat ukur untuk mengetahui tingkat stres pengasuhan pada subyek penelitian.

Pelatihan "Pengasuhan Ibu CERdaS" diberikan 8 sesi dalam 2 kali pertemuan selama seminggu. Setiap pertemuan berlangsung selama \pm 240 menit. Intervensi diberikan kepada subjek penelitian dalam kelompok eksperimen. Materi pelatihan terdiri dari materi pemahaman tentang anak autis, materi dimensi pengasuhan (meliputi; care, control dan communication), serta materi mengenali stres dan cara mengelola stres, serta diakhiri dengan

action plan.

Tabel 1

Rancangan Intervensi Pelatihan "Pengasuhan Ibu CERdaS"

\begin{tabular}{|c|c|c|}
\hline Pertemuan & Sesi & Tujuan umum \\
\hline \multirow[t]{4}{*}{ Pertama } & Sharing bersama ibu & $\begin{array}{l}\text { Peserta mempunyai kesempatan untuk bertukan informasi, dan } \\
\text { pengalaman tentang anak autis, sehingga mampu menambah } \\
\text { wawasan serta menciptakan kebersamaan dalam kelompok }\end{array}$ \\
\hline & $\begin{array}{l}\text { Video tentang anak } \\
\text { autis }\end{array}$ & $\begin{array}{l}\text { Peserta mempunyai kesempatan untuk melihat tayangan video } \\
\text { yang menceritakan tentang suka duka orangtua yang memiliki } \\
\text { anak autis, dan mendampingi anak autis hingga berhasil }\end{array}$ \\
\hline & $\begin{array}{l}\text { Pengenalan \& pemahaman } \\
\text { tentang autis }\end{array}$ & $\begin{array}{l}\text { Peserta mempunyai kesempatan untuk belajar memahami tentang } \\
\text { perkembangan anak autis, yang berupa definisi, penyebab, tanda- } \\
\text { tanda dan gejala yang dialami anak autis }\end{array}$ \\
\hline & Relaksasi & $\begin{array}{l}\text { Peserta bersama fasilitator diajak untuk merilekskan diri, setelah } \\
\text { seharian mengikuti proses pelatihan }\end{array}$ \\
\hline \multirow[t]{6}{*}{ kedua } & $\begin{array}{l}\text { Dimensi pengasuhan } \\
\text { care }\end{array}$ & $\begin{array}{l}\text { Peserta memiliki kesempatan dan latihan tentang bagaimana } \\
\text { mengasihi anak dengan cinta serta menerima anak dengan segala } \\
\text { kekurangannya }\end{array}$ \\
\hline & $\begin{array}{l}\text { Dimensi pengasuhan } \\
\text { control }\end{array}$ & $\begin{array}{l}\text { Peserta memiliki kesempatan dan latihan tentang bagaimana } \\
\text { mengontrol perilaku diri sendiri dan anak }\end{array}$ \\
\hline & $\begin{array}{l}\text { Dimensi pengasuhan } \\
\text { communication }\end{array}$ & $\begin{array}{l}\text { Peserta memiliki kesempatan dan latihan tentang bagaimana } \\
\text { berkomunikasi dan membina ikatan baik dengan anak autis }\end{array}$ \\
\hline & $\begin{array}{l}\text { Mengenal stres } \\
\text { pengasuhan }\end{array}$ & $\begin{array}{l}\text { Peserta dapat memiliki kesempatan untuk belajar memahami } \\
\text { stres pengasuhan, penyebab stres stres pengasuhan dan gejala- } \\
\text { gejala yang muncul }\end{array}$ \\
\hline & Cara mengelola stres & $\begin{array}{l}\text { Peserta memiliki kesempatan untuk belajar dan berlatih tentang } \\
\text { teknik-teknik memanajemen stres }\end{array}$ \\
\hline & Action plan & $\begin{array}{l}\text { Peserta memiliki kesempatan dan latihan untuk membuat rencana } \\
\text { tindakan yang akan dilakukan dalam menghadapi problen pada } \\
\text { perilaku anak autis mereka }\end{array}$ \\
\hline
\end{tabular}




\section{HASIL}

Hasil analisa data kuantitatif didasarkan pada hasil skor skala stres pengasuhan subjek penelitian. Skor skala stres pengasuhan saat pelaksanaan pretest, posttest dan follow-up adalah sebagai berikut:

Tabel 2

Hasil Eksperimen

\begin{tabular}{|c|c|c|c|c|}
\hline Subjek & Kelompok & Pre-test & Post-test & Follow-up \\
\hline 1 & \multirow{10}{*}{$\begin{array}{c}\text { Kelompok } \\
\text { eksperimen }\end{array}$} & 121 & 102 & 103 \\
\hline 2 & & 101 & 91 & 90 \\
\hline 3 & & 118 & 112 & 115 \\
\hline 4 & & 156 & 147 & 147 \\
\hline 5 & & 140 & 129 & 130 \\
\hline 6 & & 100 & 103 & 101 \\
\hline 7 & & 136 & 119 & 125 \\
\hline 8 & & 111 & 115 & 113 \\
\hline 9 & & 117 & 106 & 105 \\
\hline 10 & & 134 & 126 & 125 \\
\hline 11 & \multirow{10}{*}{$\begin{array}{l}\text { Kelompok } \\
\text { kontrol }\end{array}$} & 130 & 129 & 131 \\
\hline 12 & & 110 & 110 & 107 \\
\hline 13 & & 150 & 151 & 151 \\
\hline 14 & & 141 & 141 & 140 \\
\hline 15 & & 118 & 116 & 112 \\
\hline 16 & & 109 & 109 & 113 \\
\hline 17 & & 122 & 121 & 119 \\
\hline 18 & & 142 & 142 & 141 \\
\hline 19 & & 123 & 123 & 123 \\
\hline 20 & & 132 & 134 & 132 \\
\hline
\end{tabular}

Pada penelitian ini menggunakan uji Wilcoxon. Uji Wilcoxon dilakukan untuk melihat ada tidaknya perbedaan stres pengasuhan pada masing-masing kelompok. Hasil analisis tingkat stres pengasuhan pada kelompok eksperimen saat pretest dan posttest adalah sebagai berikut:

Tabel 3

Hasil uji Wilcoxon

\begin{tabular}{|c|c|c|c|}
\hline Amatan & Mean & Z & Sig \\
\hline Pretest & 123,40 & $-2,499$ & 0,012 \\
\hline Postest & 115,00 & & \\
\hline
\end{tabular}

Hasil uji beda antara posttest-follow up yang tidak signifikan memiliki arti bahwa penurunan stres pengasuhan pada kelompok eksperimen tetap mengalami penurunan. Berikut adalah tabel deskriptifnya.

Tabel 4

Hasil uji posttest-follow up

\begin{tabular}{llll}
\hline Amatan & Mean & $Z$ & Sig \\
\hline Posttest & 115,00 & $-0,060$ & 0,952 \\
\hline Follow up & 115,40 & $-0,0$ & \\
\hline
\end{tabular}

Berdasarkan data yang ada pada table 1. di atas dapat diketahui bahwa pada kelompok eksperimen skor stres pengasuhan subjek 4 adalah paling tinggi, sedangkan skor stres pengasuhan yang paling rendah adalah subjek 6 dan 2. Subjek 2, 4, 9 dan 10 mengalami penurunan stres pengasuhan saat posttest dan follow up. subjek 1,3 dan 5 juga mengalami penurunan stres pengasuhan pada saat posttest, tapi saat follow up kembali mengalami sedikit kenaikan. Pada subyek 6 dan 8 sedikit mengalami kenaikan stres pengasuhan saat posttest, tapi saat follow up kembali mengalami penurunan. Pada saat posttest yang paling banyak megalami penurunan stres pengasuhan adalah subjek 1 , sedangkan yang paling sedikit mengalami penurunan adalah subjek 3 . Subjek yang sama sekali tidak mengalami penurunan stres pengasuhan saat posttest adalah 6 dan 8 .

\section{DISKUSI}

Hasil yang diperoleh dari penelitian ini menunjukkan bahwa Pelatihan "Pengasuhan Ibu CERdaS" terbukti dapat menurunkan stres pengasuhan pada ibu dari anak autis. Berdasarkan analisis kuantitatif, didapatkan bahwa ada perbedaan skor stres pengasuhan yang signifikan antara kelompok eksperimen dan kelompok kontrol pada pengukuran setelah pelatihan. Begitu juga pada pengukuran kembali setelah satu minggu perlakuan (follow up), pada kelompok eksperimen menunjukkan masih tetapi mengalami penurunan. Hasil ini juga didukung oleh data kualitatif yang menunjukkan bahwa secara umum partisipan dalam pelatihan ini melaporkan adanya perubahan yang dirasakan setelah mengikuti pelatihan, diantaranya bertambahnya pemahaman tentang anak autis dan pengasuhan yang postitif, lebih rileks ketika menghadapi permasalahan anak, serta memiliki pemahaman tentang menejemen stres yang tepat.

Keberhasilan pelatihan yang telah dicapai dalam penelitian ini mendukung penelitian Whittingham, Saffranof, Sheffield \& Sanders (2009) yang menggunakan pelatihan dengan pendekatan triple- $P$ dalam meningkatkan pemahaman orangtua dan pada akhirnya akan menurunkan stres pengasuhan orangtua dari anak autis. Penelitian tersebut lebih berfokus pada pemahaman orangtua, sedangkan penelitian ini berfokus pada penurunan stres pengasuhan orangtua. Hasil penelitian ini juga mendukung penelitian Thompson et al (2009; Dean et al., 2003; Matsumoto, Sofronoff \& Saders, 2007; Pouretemad et al., 2009) membuktikan bahwa program triple 
$P$ efektif menurunkan perilaku distruktif anak, menunjukkan level disfungsional orangtua dan konflik orangtua-anak dalam pengasuhan yang menurun, serta meningkatkan kesehatan mental orangtua. Program triple $P$ juga dapat menurunkan masalah perilaku dan reaksi yang berlebihan pada anak, serta menurunkan konflik orangtua dengan anak, yang berefek pada meningkatnya kompetensi. Triple- $P$ juga efektif meningkatkan interaksi orangtua-anak, meningkatkan harga diri orangtua dan mengurangi stres orangtua.

Johnson dan Johnson (2001) mengemukakan bahwa ada beberapa faktor yang mempengaruhi suatu pelatihan, yaitu partisipan, iklim pelatihan, gaya belajar partisipan, strategi pelatihan, topik pelatihan, teknik pelatihan, fasilitas pendukung dan keterbatasan. Dalam hal ini keberhasilan pelatihan "Pengasuhan Ibu CERdaS" dalam menurunkan stres pengasuhan pada orangtua anak autis turut dipengaruhi oleh beberapa faktor penting yaitu modul pelatihan, trainer, dan kerjasama partisipan.

Modul pelatihan ini disusun oleh peneliti melalui review konsep-konsep dan hasil penelitian yang relevan, serta sudah dilakukan profesional judgment. Modul ini juga sudah diuji cobakan sebelumnya. Modul pelatihan ini dimodifikasi dari pendekatan triple-P untuk meningkatkan pemahaman orangtua yang memiliki anak autis oleh Whittingham et al (2009), dan pendekatan triple-P untuk dalam menurunkan intensitas gangguan perilaku anak ADHD dan menurunkan stres pengasuhan orangtua. Karena metode pelatihan tersebut terinci secara jelas dan runtut serta merupakan adaptasi dari metode triple- $P$ yang pertama kali dikemukakan oleh Sanders et al (2004) yang digabungkan dengan pendekatan kelompok, serta disesuaikan dengan keadaan partisipan, sehingga membuat modul semakin lengkap.

Metode yang dilakukan dalam pelatihan ini adalah warming up, presentasi, sharing, pemutaran video dan diskusi kelompok. Metode tersebut dipilih untuk mendukung pendekatan experiential learning. Pada pendekatan experiential learning, peserta mendapatkan pemahaman dari pengalaman atau aktivitas yang dilakukan (Prawitasari, 1998). Pada masing-masing sesi peserta diajak untuk merasakan perbedaan kondisi sebelum dan setelah penyampaian materi.

Pada sesi pembukaan, peserta pelatihan diajak untuk sharing mengenai pengalaman masingmasing orangtua dalam mengasuh anaknya. Pada kesempatan kali ini, menunjukkan universalitas pada peserta. Kelompok merasa memiliki satu pemikiran, permasalahan dan ide tentang anak autis. Mereka juga dapat bertukar pengalaman dan informasi, sehingga mampu menambah wawasan serta ketrampilan yang baru. Hal tersebut sesuai dengan pendapat Yalom (2005), bahwa pendekatan kelompok mampu menjadi salah satu terapi. Pada sesi anakku anugerah bagiku peserta dapat mengidentifikasi hal-hal yang berkaitan dengan anak autis, dari gejala-gejala pokok yang muncul pada anak autis, karakteristik dan faktor-faktor yang menjadi penyebab dari anak autis.

Sesi positive parenting, mampu menambah informasi bagi para peserta dalam proses pendampingan anak. Materi dimensi pengasuhan yang dilatihkan dalam penelitian ini dapat meningkatkan pemahaman orangtua yang pada akhirnya akan menurunkan stres pengasuhan. Dimensi pengasuhan tersebut adalah care (kasih), control (kontrol) dan communication (komunikasi), seperti yang dikemukakan oleh Phelps et al ( 2009; Whittingham et al., 2009; Osborne, 2009), khususnya dalam hubungan atau interaksi orangtua dengan anak autis.

Pada sesi mengenal stres dan manajemen stres, peserta dapat mengidentifikasi reaksi stres yang muncul. Peserta juga memahami pengaruh penilaian negatif pada suatu peristiwa terhadap munculnya stres. Setelah mempraktekkan relaksasi pernapasan, peserta merasa napas menjadi lega, lebih tenang, detak jantung teratur dan otot tubuh melemas. Peserta juga mengungkapkan perasaan yang lebih rileks. Hal ini mendukung pendapat Thompson et al (2009; Mori, Ujie, Smith \& Howlin, 2009) yang menyatakan relaksasi dapat digunakan untuk teknik dalam membantu menurunkan stres pengasuhan. Pernapasan yang dilakukan secara perlahan akan mengaktifkan sistem saraf parasimpatik yang berfungsi sebagai respon rileks (Malkani, 2004).

Materi terakhir adalah review. Menurut Goldstein (1981), tujuan dilakukannya review adalah supaya peserta dapat mengintegrasikan keseluruhan informasi yang telah dipelajari selama pelatihan, dengan mendiskusikan hal yang dirasakan pada masingmasing sesi. Secara umum, pada sesi ini peserta merasa lebih mudah mempraktekkan pemahaman yang telah diperoleh disesi sebelumnya.

Menurut Johnson dan Johnson (2001), pemberi materi menjadi bagian yang sangat penting dalam menentukan kesuksesan dan efektivitas pelatihan. Peserta menilai fasilitator memuaskan dalam penguasaan dan penyampaian materi, bersikap dan bertingkah laku, serta dalam penggunaan bahasa. 
Dari hasil observasi diketahui bahwa fasilitator memberi penguatan, merefleksikan pengalaman, memotivasi, serta berbagi pengalamannya bersama partisipan. Homogenitas tingkat pendidikan peserta mempermudah fasilitator dalam menyampaikan materi.

Partisipasi peserta juga mendukung keberhasilan pelatihan "Pengasuhan Ibu CERdaS". Menurut Goldstein (1981) keterlibatan aktif dan pengalaman belajar dapat menjadi modal terjadinya transfer belajar yang optimal bukan hanya sebagai penerima informasi pasif. Selama pelatihan, peserta cukup aktif berpendapat, menjawab pertanyaan, maupun berbagi pengalaman. Antusiasme peserta juga ditunjukkan dengan kehadiran seluruh peserta secara penih selama 2 kali pertemuan yang terdiri dari 8 sesi.

Menurit Goldstein (1981), tujuan utama suatu pelatihan adalah peserta mampu mentransfer materi yang diperoleh dalam pelatihan kedalam kehidupan sehari-harinya. Pelatihan "Pengasuhan Ibu CERdaS" ini juga menggunakan pendekatan kelompok yang ikut mendukung keberhasilan dalam penelitian ini. Pelatihan dalam setting kelompok lebih menguntungkan jika masing-masing anggota kelompok memiliki permasalahan yang relatif sama (Prawitasari, 2011). Adanya kesamaan permasalah dapat menciptakan universalitas, yaitu peserta menyadari bahwa ada individu lain yang mengalami masalah serupa dengan dirinya (Yalom, 2005). seluruh peserta pelatihan "Pengasuhan Ibu CERdaS" adalah ibu yang memiliki anak autis. Adanya kesamaan menciptakan keterbukaan diantara peserta. Kesamaan tersebut juga mempermudah peserta untuk berbagi informasi, bertukar pengalaman, serta saling memberi dukungan. Peserta pelatihan "Pengasuhan Ibu CERdaS" berjumlah 10 orang. Jumlah peserta tersebut juga mendukung efektivitas pelatihan. Menurut Yalom (2005) jumlah peserta untuk efektivitas pelatihan adalah 4-12 orang.

Secara umum, keterbatasan yang terdapat dalam penelitian ini adalah adanya ancaman terhadap validitas internal dan eksternal tentang setting ruangan yang terbatas ruang kelas sekolah, sehingga masih memungkinkan bagi peserta untuk berbagi perhatian dengan keadaan anak diluar ruangan. Shadish, Cook \& Campbell (2002) mengungkapkan tentang faktor-faktor yang berpengaruh terhadap validitas internal suatu penelitian antara lain adalah (1) Pengalaman partisipan (history). Peneliti berusaha meminimalisir ancaman tersebut dengan menyertakan kriteria eksklusi partisipan penelitian.
Meskipun demikian, ada hal-hal lain yang belum dikontrol oleh peneliti yaitu adanya pertukaran informasi dan buklet yang dilakukan antar peserta diluar sesi. Selain itu, peneliti juga belum dapat meminimalisir faktor-faktor diluar pelatihan yang dapat berpengaruh terhadap menurunnya stres pengasuhan, misalnya tipe kepribadian atau dukungan dari keluarga. (2) Testing, pada penelitian ini dilakukan dua kali pengukuran, yaitu sebelum dan setelah pelatihan. Adanya dua kali pengukuran dalam rentang yang tidak terlalu panjang dapat menimbulkan familiritas terhadap instrumen testing (skala).

\section{KESIMPULAN}

Penelitian ini dilakukan untuk menjawab hipotesis yang diajukan bahwa pelatihan "Pengasuhan Ibu CERdaS" berpengaruh menurunkan tingkat stres pengasuhan ibu dari anak autis. Setelah dilakukan analisis dengan menggunakan Wilcoxon signed rank (non parametrik), menunjukkan hasil bahwa pelatihan "Pengasuhan Ibu CERdaS" menurunkan tingkat stres pengasuhan ibu dari anak autis. Peranan perolehan skor pada kelompok eksperimen saat sebelum perlakuan (pretest) dan sesudahnya (posttest) mengalami penurunan yang signifikan. Begitu juga pada uji beda tingkat stres pengasuhan pada posttest kelompok eksperimen dan posttest kelompok kontrol menunjukkan adanya perbedaan yang signifikan, kelompok eksperimen mengalami penurunan tingkat stres pengasuhan dibanding kelompok kontrol. Hasil uji beda antara posttest dan follow up kelompok eksperimen ternyata tidak mengalami perubahan yang signifikan, maka artinya adalah pelatihan "Pengasuhan Ibu CERdaS" juga tetap efektif menurunkan tingkat stres pengasuhan setelah 1 minggu (follow up) pelaksanaan pelatihan. Adapun saran-saran yang dapat diajukan adalah:

Saran kepada peneliti selanjutnya. Penelitian ini merupakan penelitian pendahuluan yang mencari alternatif program untuk permasalahan pengasuhan melalui edukasi tentang ketrampilan pengasuhan bagi orangtua dari anak autis. Meskipun secara umum pelatihan berpengaruh dalam menurunkan tingkat stres pengasuhan ibu dari anak autis, namun pelatihan ini agar lebih optimal maka perlu menyempurnakan modul dan prosedur pelaksanaannya.

Saran kepada subyek penelitian. Berdasarkan hasil pengumpulan data kualitatif penelitian di atas yang menyebutkan bahwa hal yang paling dibutuhkan oleh orangtua dari anak autis adalah teman sharing yang memiliki nasib sama. Dari hal 
tersebut maka akan lebih baik ketika para orangtua membuat suatu kelompok paguyuban, sehingga segala permasalahan dapat terselesaikan dan stres

\section{DAFTAR PUSTAKA}

Abidin, R. R. (1995). Parenting Stress Index Profesional Manual. 3 rd. Ed. Odessa FL: Pasychological Assessment Resources

Cusinato, M. (1994) Parenting over the family Life Cyrcle. Dalam L 'Abate, L. (Ed). Handbook of Developmental family Psychology and Psychopathology. New York: John Wiley \& Sons, Inc

Dabrowska, A., \& Pisula, E. (2010). Parenting Stress and Coping Syle in Mothers and Fathers of Pre-School Children with Autism and Down Syndrome. Jornal of Intellectual Disability Research, Vol 54, 266-280

Davis, N, O, \& Carter, A, S. (2008). Parenting Stress in Mothers and fathers of Toddlers With Autism Spectrum Disorders: Associations with Child Characteristic. Journal Autism Dev Disorder, $38,1278-1291$

Dean, C., Myors, K., \& Evans, E. (2003). Community Wide Implimintation of a Parenting Program: The South East Sydney Positive Parenting Project. Australian e journal for the advancement of mental health. Vol. 2, 154-171

Dinkmeyer, S. D., McCay, G., Dinkmeyer, J. D., McCay, J. (1997). STEP: The Parent Handbook. Circle Pines, MN: American Guidance Service

Dunn, E. M., Burbine, T., Bowers, A. C., A. C., \& Tanleff-Dunn, S. (2001). Moderators of Stress in Parent of Children With Autism. Journal of Community Mental Health. Vol. 37, 451-477

Emawati. (2008). Mengenal Lebih Jauh Sekolah Inklusi. Pedagogik Jurnal Pendidikan. Vol. 5, 25-35

Febriana, N. (2008). Kromosom Abnormal Penyebab Autisme. Dalam: Info Aktual Autisme, Available From: http: //www.litbang.depkes.go.id. (Accessed: 09 Juli 2011) pengasuhan juga akan menurun. Latihan mengelola stres dengan berlatih relaksasi juga dapat membantu menurunkan stres pengasuhan.

Gillberg, C. \& Wing, L. (1999). Autism: Not An Extremely Rare Disorder. Acta Psychiatr Scand, Vol. 9, 399-406

Goldstein, A. P. (1981). Psychological Skill Training : The Structured Learning Technique. New york : Pergamon Press

Johnson, C. A., \& Johnson, F. P. (2001). Joining Together: Group Theory and Group Skills. Boston: Allyn \& Bacon

Kadesjo, B., Gillberg, C., \& Hagberg, B. (1999). Autism and asperger syndrome in sevenyear old children : a total population study. Journal of Autism and Developmenttal Disorders, Vol. 29, 327-332

Kazdin, A. E., Siegel, T. C., \& bass, D. (1992). Cognitive Problem Solving Skills Training and Parent Management Training in The Treatment Of Antisocial Behavior in Children. Journal of Consulting and Clinical Psychology. Vol. 60, 733-747

Kazdin, A. E. \& Whitley, M. K. (2003). Treatment of Parental Stress to Enhance Therapeutic Change Among Children Referred for Agressive and Antisocial Behavior. Journal of Consulting and Clinical Psychology. Vol. 71, 504-515

Malkani, V. (2004). Stress \& Anger: All You Wanted to Know About. (Terjemahan). Jakarta: PT Bhuana Ilmu Populer Kelompok Gramedia

Matsumoto, Y., Sofronoff, K., \& Sanders, M. (2007). The Efficacy and Acceptability of The Triple P - Positive Parenting Program with Japanese Parents. Behavior change. Vol. 24, 205-218

Mori, K., Ujie, T., Smith, A, \& Howlin, P. (2009). Parental Stress Associated with Caring for Children With Asperger's Syndrome or Autism. Pediatric International, Vol. 51, 364-370

Neitzel, J. (2010). Positive Behavior Supports for 
Children and Youth with Autism Spectrum Disorders. Préventing School Fallure. Vol 54 (4), 247-255

Osborne, L, A. (2009). The Relationship Between Parenting Stress and Behavior Problems of Children With Autistic Spectrum Disorders. Counsil for Exceptional Children, Vol. 76, 54-73

Osborne, L. A. \& McHugh. (2009). Parenting Stress Reduces the Effectiveness of Early Teaching Interventions for Autistic Spectrum Disorders. J Autism Dev Disord, Vol. 38, 1092-1103

Pediatric. (2004). Effective Discipline for Children. Child health, Vol. 9, No. 1. (www.cps.ca/ english/statement/PP/PP04-01. pdf)

Phelps, K, W., McCammon, S, L., Wuensch \& Golden, J, E. (2009). Enrichment, Stress, and Growth from Parenting an Individual with An Autism Spectrum Disorder. Journal of Intellectual \& Developmental Disability, Vol. 34(2), 133141

Pouretemad, H. R., Khooshabi, K., Roshanbin, M., \& Jadidi, M. (2009). The Effectiveness of Group Positive Parenting Program On Parental Stress of Mothers of Children With Attention-Deficit/ Hyperactivity Disorder. Archives of Iranian Medicine, Vol. 12 (1), 60-68

Prawitasari, J. E. (1991). Pendekatan Kelompok Dalam Konseling dan Psikoterapi. Malang: IKIP Malang

Prawitasari, J. E. (1998). Pengalihan metode Action Research Ke Petugas Puskesmas Untuk Meningkatkan Perilaku Sehat Masyarakat. Anima, Vol. XIII (52), 323-333

Prawitasari, J. E. (2011). Psikologi Klinis(Pengantar Terapan Makro). Jakarta: Pernerbit Erlangga

Puterakembara. (2008). PBB Menetapkan tanggal 2 April Sebagai Hari Peduli Autisme Sedunia. Diunduh 10 Oktober, 2011, dari http://www. puterakembara.org/ pressreleasedYAI.pdf
Ruminem. 2005. Hubungan Pengetahuan dan Sikap Ibu Tentang Autisme dengan Partisipasi Ibu dalam Penanganan Anak Autis Dirumah. Tesis. Program Studi Ilmu Kesehatan Masyarakat

Sanders, M. (2003). Triple P - Positive Parenting Program: A Population Approach To Promoting Competent Parenting. Australian E journal For The Advancement of Mental Health. Vol. 2, 324-335

Sanders, M., Mazzuchhelli, T., \& Studman, L. (2004). Stepping Stones Triple P- An Evidence- Based Positive Parenting Program For Families With A Child Who Has Dissability: Its Theoritical Basis and Development. Journal of Intellectual and Developmental Dissability. Vol. 29 (3), 265-283

Shadish, W. R., Cook, T. D., \& Campbell, D. T. (2002). Experimental and Quasi-Experimental Design for Generalized Causal Inference. New York: Boston

Sutadi,R. (2002). Autisme \& Applied Behavior Analysis (ABA)/Metode Lovaas, Dasar-Dasar, Teknik dan Kiat Praktis, Klinik Intervensi Dini Autisme. Jakarta: Jakarta Medical Center

Thompson, M, J, J., Ayres, M., Mead, S., Bitsakou, P., Weeks, A., Thompson, P, \& Barke, E, J, S, S. (2009). Asmall-Scale Randomized Controlled Trial of The Revised new Forest Parenting Programme for Preschoolers With Attention Deficit Hyperactivity Disorder. Eur Child Psychiatry, Vol. 18, 605-601

Whittingham, K., Saffranof, K., Sheffield, J., Sanders, M. R. (2009). Stepping Stones Triple $\mathrm{P}$ : An RCT of a Parenting Program with Parents of a Child Diagnosed with an Autism Spectrum Disorder. Journal Abnormal Child Psychology. Vol. $37,469-480$

Yalom, I. D. (2005). The Theory and practice of group psychotherapy. New York: Basic Books

Yusuf, E. Y. (2003). Autisme: Masa Kanak, Program Studi Psikologi Fakultas Kedokteran Universitas Sumatera Utara, Digitized by USU digital Library 